\title{
ELE VEIO COMIGO: \\ AUTOR, NARRADOR, GÊNERO E DOMINAÇÃO MASCULINA EM UM ROMANCE DE ELVIRA VIGNA
}

Ana Cláudia Paschoal

\begin{abstract}
RESUMO: Este artigo visa a analisar as figuras do autor e do narrador dentro do romance policial Deixei ele lá e vim, de Elvira Vigna e, dessa forma, discutir a dimensão do pensamento androcêntrico em que se baseiam certas estruturas sociais. Sendo assim, reflexões sobre autor e narrador, bem como questões relativas a gênero e à dominação masculina são fundamentais para a elaboração deste estudo. Demonstra-se que a protagonista do romance examinado é construída de modo a revelar adesão às estruturas de dominação masculina que norteiam suas relações dentro de uma narrativa repleta de ambiguidades.
\end{abstract}

PALAVRAS-CHAVE: Autor; Dominação Masculina; Gênero; Narrador.

Um crime que jamais é esclarecido. Uma narradora que confessa que mente. Um romance policial em que o crime é o menos importante a esclarecer. Assim é o romance Deixei ele lá e vim, de Elvira Vigna, que tem como traço marcante a constante mobilidade das situações que permeiam o enredo cuja protagonista tem um passado indeterminado, uma família indeterminada, um trabalho indeterminado, um gênero indeterminado. Tratase de uma habilidosa narradora que estrutura seu relato com base em seus interesses em revelar somente o que lhe é possível ou o que lhe é conveniente.

\footnotetext{
* Doutoranda em Literatura Brasileira pela Universidade Estadual de Marigá (Uem). Mestre em Literatura Brasileira pela Uem.
} 
Muito tempo depois de um acontecimento que jamais é elucidado e que motiva o relato de Shirley Marlone (cujo nome nem mesmo pode ser considerado verdadeiro), o leitor toma conhecimento de todas as incógnitas que cercam a vida dela: sua distância da família, o motivo pelo qual abandonou seu emprego, sua ocupação anterior à sua inscrição para um teste cinematográfico, seus amores pregressos, sua constante necessidade de deslocamento e até seu verdadeiro nome são desconhecidos pelo leitor, graças à engenhosidade de Vigna em manipular os detalhes da narrativa que, espalhados ao longo do enredo, distraem e desconcertam quem se aventura a entrar no universo dessa autora que trata de importantes questões através do romance aqui analisado.

Partindo-se da figura de uma narradora diferenciada e interessante, este artigo tem como objetivo principal problematizar a autoria do enredo vivido pela protagonista do romance, vez que se trata de uma narrativa em que ambiguidades e incertezas dão o tom do narrado. Como objetivo secundário, este trabalho propõe-se a discutir as marcas da dominação masculina evidenciadas na construção do enredo cuja protagonista se esforça para conciliar sua compleição física com sua identidade feminina.

Em um primeiro momento, observa-se a importância da distinção entre as figuras do narrador e do autor da narrativa e, mais adiante, examina-se de que modo o pensamento androcêntrico contribui para a elaboração de uma ideologia que dá margem a alguns esclarecimentos acerca do mistério que envolve uma protagonista que confessa: "invento não só para trás, o que já aconteceu, mas também o que vai acontecer”.

\section{Shirley Marlone - inventora de verdades}

Um enredo emitido em primeira pessoa deixa-nos à mercê de fatos, razões e sentimentos de um protagonista que mantém o leitor distanciado do que é contado. É apenas o narrador em primeira pessoa quem nos guia através do narrado, a partir de seu ângulo particular de visão sobre a trama em que atua. Shirley Marlone, como assim se diz chamar a narradora do romance Deixei ele lá e vim, é a sua protagonista e em tal condição fala o que vê e o que sente, assumindo total responsabilidade sobre o narrado. 
Moradora do Morro do Vidigal, Shirley é instada por sua amiga e vizinha Meire a participar de um teste cinematográfico que está ocorrendo nas instalações de um hotel cinco estrelas onde esta trabalha. Não obtendo sucesso, Shirley fica transitando pelo hotel, onde janta e, tarde da noite, reúne-se com Meire e Dorothy (chamada de Dô, uma das atrizes escolhidas no teste) na areia da praia vazia diante do hotel já referido. Na manhã seguinte, corre a notícia do desaparecimento de Dô - sem que se saiba se por acidente, por suicídio ou por assassinato - aventado a partir do momento em que uma das sandálias dela é encontrada na boca de um cão que circula pelas imediações.

A franqueza de Shirley é desconcertante ao narrar, dez anos depois, o fato que lhe marcaria a vida, cercando-o de observações, ironias e ambivalências, a começar pelos nomes das personagens: sua mãe é chamada de Lili ou Lindomar; as atrizes são Agrid ou Egrid, Quinde ou Quilde, Dorothy ou Dô ou Maria das Dores; o produtor do filme é chamado de Bubi, Bibo, Bubil, Bubby, Bibbi, Bibil ... Sua permanente necessidade de mudança passa por planos de se transferir para outra cidade a fim de recomeçar a vida ou de voltar para a casa da família e tomar posse do que lhe cabe ou ainda de deixar a vida de ocupações esporádicas para tentar a carreira de atriz de cinema ou até mesmo trocar as próteses de silicone que tem nos seios para que fiquem mais adequados. Existe, ainda, a possibilidade de que

ela seja a criminosa, mas a ênfase é do sentimento de deslocamento da protagonista. Ela está constantemente procurando "portas de saída”, escondendo seus olhos atrás de óculos escuros, já que não é possível esconder-se dos olhares alheios. Há controle sobre o volume de sua voz, seu silicone está torto, seus pés e suas pernas nem sempre respondem (LEAL, 2012, p. 46).

A elaboração da identidade de Shirley é um processo em constante movimento, eis que “a 'identidade’ só nos é revelada como algo a ser inventado, e não descoberto, como alvo de um esforço, 'um objetivo', como uma coisa que ainda se precisa construir a partir do zero" (BAUMAN, 2005, p. 21-22). Seu esforço em construir seu corpo de acor- 
do com sua essência feminina esbarra constantemente na impossibilidade física de expressar a imagem que ela tem de si e na vigilância que ela exerce sobre a exibição dessa imagem, já que Shirley atua em uma sociedade que reconhece basicamente as identidades de gênero masculino e de gênero feminino, em cuja "matriz cultural por intermédio da qual a identidade de gênero se torna inteligível exige que certos tipos de 'identidade' não possam 'existir'” (BUTLER, 2003, p. 39).

Usando a expressão "deixei ele lá e vim”, Shirley conta sobre como abandonou as cinzas de seu pai na funerária; é também a expressão usada para contar como deixou Bubby atônito ao receber a notícia sobre o desaparecimento de Dô; assim também afirma que sempre deixa para trás um de seus "eus" ou até mais de um; com esse mesmo bordão declara que, à beira da piscina do hotel, ensaiou "mais uma história do tipo deixei ele lá e vim". Trata-se de uma frase de efeito cheia de ambiguidades, pois o sentimento de inadequação que tanto persegue Shirley tem como um dos motivos o desconforto com seu próprio gênero, que ao final se revela quando ela confessa: "fecho a porta do banheiro quando, com a pinça, tiro os pelos duros que ainda nascem (poucos) no meu queixo". Shirley é um travesti. Porém, não pode ser esquecido um pequeno e significativo detalhe: tudo pode ser mentira de uma narradora que assume inventar histórias, justificando o porquê: "entre outros motivos, porque gosto de histórias, sempre gostei”.

Shirley assume, segundo GÓIS (2013, p. 155), “a condição de quem mente sem provocações. [...] No caso de Marlone, contar a história de acordo com suas tintas oferece a chance de existir como ela gostaria de ter sido desde o nascimento, uma mulher". Com efeito, ao longo do romance Shirley insiste em deixar para trás sua identidade masculina, pela qual é constantemente perseguida e que se revela de modo sutil em pequenos instantâneos, como se escapasse momentaneamente da prisão física em que é mantida pela personagem. Essas escapadelas deixam entrever que "a voz do protagonista é feminina, seu corpo é dissimulado. Afinal, quem é a dona da voz, se o corpo nem sempre foi conforme o narrado?" (GÓIS, 2013, p. 151). E como Shirley Marlone transita sempre entre mundos bem opostos - entre o Morro do Vidigal e o hotel cinco estrelas; entre a vida de 
prostituição e o relacionamento estável com Tião, entre o passado escamoteado e o presente disfarçado, entre a condição feminina e o gênero masculino -, o romance Deixei ele lá e vim estabelece uma dúvida que se sobrepõe ao mistério do desaparecimento de Dô e nos leva a querer elucidar um mistério maior : quem é Shirley Marlone?

\section{Shirley Marlone - criador ou criação?}

É sabido que o eu narrador diferencia-se do en escritor, pois "a voz que fala é a do escritor, por meio da voz alheia, criada para a ocasião e de acordo com o que pretende no momento. De onde a distância psicológica se realizar em dois planos: 1) entre o escritor e o narrador e 2) entre o narrador e a história" (MOISÉS, 2004, p.363). De maneira engenhosa, Deixei ele lá e vim é construído destacando um nível de enunciação (Shirley vivendo sua história) de outro (Shirley narrando a história protagonizada por Shirley), pois Shirley aparece, simultaneamente, no mencionado romance como um ser que narra e um ser que é narrado e "o texto literário pode tirar partido do fato de os dois 'eus' não serem necessariamente coincidentes" (SANTOS; OLIVEIRA, 2001, p. 18).

Narrativa ágil, o romance Deixei ele lá e vim é elaborado de maneira a indicar uma distância entre quem narra e quem vive as aventuras de Shirley Marlone - e que não são a mesma pessoa. É um estratagema delicadamente empregado por Vigna como distrator eficiente a desviar a atenção do leitor para outros detalhes que possivelmente elucidariam os mistérios que compõem o enredo (o destino de Dô ou o passado de Shirley, por exemplo) mas que jamais são esclarecidos.

A princípio, a narrativa delineia-se sobre o que TODOROV (2013, p. 95-96) classifica como romance de enigma, em cuja base "encontramos uma dualidade, e é ela que nos vai guiar para descrevê-lo. Esse romance não contém uma, mas duas histórias: a história do crime e a história do inquérito". Cumpre salientar que em Deixei ele lá e vim a história do crime não tem exatamente um desdobramento: o leitor desconhece o rumo das investigações a respeito do desaparecimento de Dô, não há esclarecimento qualquer sobre a identidade dos envolvidos no ocorrido, sequer existe a certeza de que se trata de um cri- 
me. Por outro lado, se a primeira história versa sobre o desaparecimento de Dô, a segunda história é contada por alguém "que reconhece explicitamente estar escrevendo um livro: ela consiste, de fato, em explicar como essa própria narrativa pode ser feita, como o próprio livro é escrito" (TODOROV, 2013, p. 96).

Súbitos deslocamentos temporais do narrado tornam bastante discretas as pistas de que existe um alguém a escrever a história que Shirley protagoniza e compartilha com o leitor, o qual introduz uma segunda voz na narração dos fatos. Esse hábil arranjo entre enunciação discursiva (o narrador que fala no momento da ação) e a narrativa propriamente dita (o narrador que conta as aventuras de Shirley) é um componente que bem merece consideração dentro da elaboração do romance.

Como “o narrador não é quem efetivamente escreve o livro (é possível, porém, que o narrador 'encene', 'simule' a ação de escrevê-lo). [...] O narrador é uma 'criação do autor'. A voz do narrador é a 'ficção de uma voz' " (SANTOS; OLIVEIRA, 2001, p. 3), a voz de Shirley-personagem está contida na voz de Shirley-autora, mas não corresponde a esta. O recurso de uma falsa autoria - vez que se trata de um suposto relato autobiográfico de Shirley Marlone - torna-se um artifício que reforça a verossimilhança na construção do que é narrado, estimulando a curiosidade do leitor a respeito do desenlace de uma história policial ao criar nele a ilusão de estar tomando conhecimento da verdade contada por uma protagonista que, por várias vezes, confessa que mente. Essa falsa autoria conduz o leitor a procurar e catalogar, atentamente, os menores detalhes (a sandália de Dô, o toco de charuto que Buby deixa cair na praia, os pezinhos da esposa de um hóspede, o boné xadrez perdido por um estrangeiro, o cão sem dono que é cuidado por funcionários do hotel etc.) como pistas para a resolução do mistério que se estabelece na trama, seja ele um acidente, um suicídio ou um crime. E isso acaba por desviar o leitor de um detalhe: ao longo do romance, temos fraturas da narrativa, pausas assumidas pelo alguém que está perante a tela do computador, escolhendo fatos e remontando sua sequência numa seleção daqueles que interessam a quem os narra. Mas quem narra os fatos: quem os vivenciou ou quem afirma que " $\mathrm{Na}$ tela preta do meu computador (e o fato de ela estar 
preta me informa que há mais de cinco minutos não mexo nele) ressurge agora o que vi no preto à minha frente naquela noite" (VIGNA, 2006, p. 44)? A partir daí, tem-se uma dicotomia entre Shirley-personagem (que vive o narrado) e Shirley-autora (que narra as aventuras de sua criação literária) - ambas concebidas pela autora implícita, denotando mais um romance em que "Elvira Vigna apresenta protagonistas e narradoras que forjam as próprias vidas nos livros, ao mesmo tempo em que forjam seus discursos " (GÓIS, 2013, p. 147).

Pode-se perceber um deslocamento na sequência narrativa no momento da acusação que Shirley-personagem faz a Bubby/Bubu, envolvendo-o no desaparecimento de Dô e causando a ele um grande desconcerto: “Olho para ele, um quadro. A geleia no canto da boca, o branco do rosto igual ao da camisa polo, onde reparo num cavalinho bordado. Bubu só não cai porque está apoiado, agora com as duas mãos, na espreguiçadeira” (VIGNA, 2006, p. 89). Logo após, dá-se rápido salto para o tempo presente, tempo em que a pessoa que está diante do computador declara que "Neste momento já começo a desenhar a cena para o futuro, já começo a contar como contaria depois, num futuro que afinal acabou não vindo" (VIGNA, 2006, p. 89). O pronome demonstrativo neste e o advérbio de tempo já, usados por quem cria o enredo, mostram claramente o instante em que a elaboração da narrativa precisa ser suspensa, examinada e ajustada ao que já foi previamente criado como "realidade" vivida pela protagonista. Não se trata do momento vivido por Shirley-personagem e sim o momento em que quem está construindo a narração inicia os acertos necessários para adequá-la a um momento narrativo futuro - como bem demonstra o verbo contaria, empregado no futuro do pretérito.

É também uma ruptura temporal da narração que se vê na passagem em que Shirley-personagem se torna alvo da desconfiança de Bubby quanto ao desaparecimento de Dô. Shirley-personagem faz uma série de elucubrações a respeito das possibilidades sobre o destino de Dô, encerrando-as com um “O que, sim, falo, é que não quero mais saber onde Dô está ou não está, que eu não controlo na verdade o destino de ninguém, nem 
sequer o meu" (VIGNA, 2006, p. 107). A partir daí percebe-se a existência de uma outra pessoa que se distancia desse momento crucial:

[...] entrei nisso por pura solidão, por não saber de mim, coisa que bate em pessoas nas piscinas de hotéis, nas ruas e rodoviárias de grandes cidades, em quartos vazios, com vista ou sem, estando ou não em frente de um computador, como agora que escrevo isto, as paredes brancas manchadas, o cinza da mesa.

E que, em geral, mal percebo o que se passa à minha volta. Bibu me olha.

(Ele está sentado no sofá da minha casa, enquanto escrevo isto) (VIGNA, 2006, p. 107).

Os termos agora e isto demonstram o tempo da elaboração da narrativa e não o tempo dos acontecimentos protagonizados por Shirley. Além disso, o termo minha casa não poderia ser usado por Shirley-personagem ao tempo em que viveu o enredo, posto que não tinha moradia fixa na época e pensava seriamente em voltar para a casa da família, no estado de São Paulo. Mais uma vez, as marcas do texto indicam a suspensão da narrativa e o deslocamento para o instante presente, momento em que Shirley-autora - a pessoa em frente ao computador - está construindo o enredo.

Mais adiante, ao ser indagada por Bubu de maneira bem incisiva ("O que você queria quando me acusou pelo desaparecimento de Dorothy?”), Shirley-personagem confessa que não sabia o que queria no momento e ocorre uma quebra na narração com uma interferência de Shirley-autora, no presente: “(Só preciso mesmo saber o que quero agora, sentada no computador. Desconfio que é o mesmo que quero sempre: ir embora)" (VIGNA, 2006, p. 123). O mesmo tipo de fratura temporal acontece na narrativa quando o leitor toma conhecimento da vida recente do casal Shirley e Tião (como Bubu/Bubby pede para ser chamado) e que nos leva a Shirley-autora, que, diante da tela do computador, diz sobre o companheiro: "Ele está agora no sofá, à minha esquerda, um pouco atrás de mim mas não o suficiente para ler o que escrevo. Aguarda" (VIGNA, 2006, p. 142). Também existe esse deslocamento do passado narrado para o presente da narração quan- 
do se sabe da presença constante e constrangedora de Tião à volta de Shirley-autora, que se queixa de suas ansiedades: "Ou mesmo um escuro total. E que é justamente quando preciso me restringir, por causa da presença dele, ao quadrado preto de um computador" (VIGNA, 2006, p. 144), ou mesmo quando revela que "no quadrado preto (preciso mexer em alguma tecla para manter Tião no sofá), me volta a imagem que nunca vi” (VIGNA, 2006, p. 145). Ao longo do romance, há passagens em que percebemos que Shirleypersonagem está entregue à manipulação de Shirley-autora. A atmosfera de artifício ainda é reforçada pelo jogo ardiloso da narração da pseudoautora, comandado através de desvios temporais para o presente, para o momento da elaboração do narrado.

A habilidade de Vigna desdobra a narração da experiência vivida pela protagonista pois, através das quebras temporais narrativas, desenvolve o enredo de modo a demonstrar dois planos: o plano da aventura vivida por Shirley-personagem e o plano do relato dessa aventura criado por Shirley-autora. Aquela, confessadamente mentirosa, vive uma "história policial" inventada por esta, que está diante da tela do computador, selecionando o que vai ser narrado, organizando os fatos a narrar, suspendendo ou desviando os rumos da história. O ponto de vista de Shirley-autora serve para que ela possa "a um só tempo, se esconder e se revelar: o disfarce permite a eclosão dos conteúdos profundos da mente do ficcionista” (MOISÉS, 2004, p. 363).

A estrutura de deixei ele lá e vim assemelha-se à de uma matrioska, a bonequinha russa que, aberta ao meio, revela em seu interior uma réplica menor de si que, por sua vez, se aberta ao meio revela em seu interior outra réplica menor ainda de si. No romance, existe uma Shirley-personagem, que supostamente narra uma série de experiências emocionantes vividas dentro de um enredo edificado por Shirley-autora, a que fica diante do computador, na medida em que se observa que esta constitui uma persona criada pela autora implícita do romance para falar do modelo de dominação masculina que se erige na representação da identidade de Shirley-personagem. 


\section{Shirley Marlone - ela ou ele?}

Deixei ele lá e vim é mais um dos romances de Vigna os quais "trabalham em um gênero literário 'falsamente' policial. Apesar de suas narrativas poderem ser assim 'vendidas', pois sempre aparecem cadáveres, policiais e crimes, não é a 'resolução' de um assassinato o principal mote do enredo" (LEAL, 2010, p. 87-88). A questão mais interessante do enredo apresenta-se em meio a lacunas e ambiguidades que se devem a uma série de fatores e são consideradas uma

consequência não apenas da opacidade da visão central do narrador e do tecido volátil de sua memória, mas também de seu empenho em colocar em dúvida a veracidade de sua própria narração, evidenciando, portanto, a possibilidade de mentira da representação. E essa ambiguidade é o ponto mais forte do romance, pois, como resultado disso tudo, abre-se um horizonte de perspectivas para o exercício do juízo crítico do leitor(a), que deve transpor o binarismo entre verdade e mentira rumo ao estabelecimento de outra relação, a de que tudo nem é verdadeiro nem falso, mas construído com efeitos de verdade. (NEVES; ZOLIN, 2014, p. 135)

Muitas são as possibilidades que se abrem na leitura do romance Deixei ele lá e vim e muitas delas apontam para uma direção incontestável: o percurso de Shirley - seja ele real, imaginado, disfarçado, relembrado ou forjado - dá-se em meio a uma estrutura social completamente edificada sobre os ditames da dominação masculina, o tempo todo a demonstrar que

a força da ordem masculina se evidencia no fato de que ela dispensa justificação: a visão androcêntrica impõe-se como neutra e não tem necessidade de se enunciar em discursos que visem a legitimála. A máquina social funciona como uma imensa máquina simbólica que tende a ratificar a dominação masculina sobre a qual se alicerça: é a divisão sexual do trabalho, distribição bastante estrita das atividades atribuídas a cada um dos dois sexos, de seu local, seu momento, seus instrumentos. (BOURDIEU, 2014, p. 23-24) 
Shirley-personagem é criada de modo a confirmar um pensamento constituído a partir de bases androcêntricas: seu corpo não atende aos padrões sonhados pelo público masculino; as mulheres "loironas e gostosas" à sua volta são mostradas como fúteis, interesseiras ou desfrutáveis; sua amiga Meire é constantemente agredida pela companheira Tereza, numa reprodução da matriz heterossexual de violência doméstica; ainda que tenha capacitação profissional em uma área específica, por ser travesti, só pode exercer a prostituição para ganhar a vida. São conceitos e preconceitos típicos de uma sociedade em que a visão masculina é "continuamente legitimada pelas próprias práticas que ela determina: pelo fato de suas disposições resultarem da incorporação do preconceito desfavorável contra o feminino instituído na ordem das coisas" (BOURDIEU, 2014, p. 53).

O desconforto para com o próprio corpo, manifestado por Shirley em inúmeras passagens do romance, é um dos mais fortes indicativos de que ela, por mais que tente, jamais poderá alcançar os modelos de beleza que atendem ao gosto masculino vigente. A referência a sua insatisfação com as próteses de silicone nos seios e a vontade de modificá-las de modo que fiquem mais naturais denotam que Shirley sabe que "a liberdade de alterar qualquer aspecto e aparência da identidade individual é algo que a maioria das pessoas hoje considera prontamente acessível, ou pelo menos vê como uma perspectiva realista para o futuro próximo" (BAUMAN, 2005, p. 91). Assim, a oportunidade de mudar sua compleição corporal é bastante exequível; porém, em várias ocasiões Shirley confessa sua impropriedade física em relação a suas aspirações estéticas - que jamais serão alcançadas - em mostras sutis de constante desapontamento, como ao dizer que "um filho que não tenho como ter aperta meu diafragma" (p. 56) ou ao desabafar sobre "a injustiça do mundo, o porquê de eu não ter nascido loirona” (p. 11). A impossibilidade física de Shirley atingir o ideal feminino confirma que "é a matriz heterossexual que dita os contornos da materialização dos corpos, que estabelece as fronteiras. Ou seja, quem não se enquadra neste padrão de relacionamento, está excluído da rede de significação cultural” (MIRANDA, 2008, p. 52). 
O não enquadramento em um modelo de beleza física desdobra-se na decepção manifestada por Shirley ao dizer, quando observa suas pernas, que "podem muito bem ser de madeira, e chego à pesarosa conclusão que me acompanha desde sempre: sou do tipo que não tem jeito. Correr eu corro, mas não sambo" (p.20), ou mesmo quando, ao ser observada por um hóspede do hotel, afirma que "ele confere se a avaliação dos meus peitos e coxas continua a mesma. Não consigo saber se a avaliação é boa ou ruim. Acho que ele também não" (p. 83). A inadequação física sentida por Shirley demonstra que "a relação de Marlone com sua corporalidade ainda apresenta uma camada de desconforto, parte dele propiciado pela luta permanente de ser reconhecida por uma identidade e também de ter um corpo respeitado na condição que assume” (GÓIS, 2013, p.157).

Trata-se do mesmo embaraço com seu corpo sentido quando relata que "Bubi [...] me olha com mais atenção do que preciso e mereço. Penso que é porque estou de pé, me vestindo. Não gosto que me olhem” (p. 109). Dá-se a decepcionada constatação da impertinência da "dureza da pele em volta das unhas do pé" (p. 72), além do pudor com que confessa que "fecho a porta do banheiro quando, com a pinça, tiro os pelos duros que ainda nascem (poucos) no meu queixo" (p. 144) e que "a bunda de Dô, que rebolava afetada, enorme, tão parecida com a que eu não tinha quando eu também, caricato, ridículo, falso, rebolava para tentar ser alguma coisa, qualquer coisa” (p. 145). Achando-se caricato, ridículo, falso ao emular o gestual feminino, Shirley "embaralha as fronteiras entre o biológico e o cultural, o real e o fictício, a verdade e a mentira porque compartilha das narrativas dominantes sobre gênero e sexualidade. Sua identidade é produzida em contraponto mas também em sintonia com esses discursos" (MIRANDA, 2008, p. 54). A fixação invejosa de Shirley pelas nádegas de Dô revela um frustrado desejo de feminilidade, pois "o corpo tem sua frente, lugar da diferença sexual, e suas costas, sexualmente indiferenciadas e potencialmente femininas" (BOURDIEU, 2014, p. 32). Seu desconforto quanto à impossibilidade física de atingir o ideal feminino aponta claramente que "é a matriz heterossexual que dita os contornos da materialização dos corpos, que estabelece as fronteiras. Ou seja, quem não se enquadra neste padrão de relacionamento, está excluído 
da rede de significação cultural" (MIRANDA, 2008, p. 52). Tudo isso atesta o constrangimento causado por um corpo não configurado de acordo com o padrão social dominante, confirmando que

A probabilidade de vivenciar com desagrado o próprio corpo (forma característica da experiência do "corpo alienado"), o malestar, a timidez ou a vergonha são tanto mais fortes quanto maior a desapropriação entre o corpo socialmente exigido e a relação prática com o próprio corpo imposta pelos olhares e as reações dos outros. Ela varia nitidamente segundo o sexo e a posição no espaço social. (BOURDIEU, 2014, p. 95)

Uma construção preconceituosa também é demonstrada nas ironias que Shirleypersonagem destila em direção às mulheres que compartilham de sua trajetória, as quais são depreciativamente vistas. Como na passagem em que se vê na praia, sozinha com Dô que lhe conta como encontrou dinheiro em uma gaveta, Shirley diz ter feito uma piada não compreendida pela interlocutora e então arremata ironicamente: "É uma tentativa de brincadeira, mas ela não acompanha, não entende quase nada do que eu falo. Eu, para meu azar, entendo tudo do que ela fala" (VIGNA, 2006, p. 57). E bem antes desse encontro, também não escapam às críticas as moças que foram escolhidas no teste cinematográfico do qual Shirley nem mesmo chegou a participar. Após o final da seleção, quando as aprovadas se dirigem à mesa do produtor, Shirley afirma: "me sinto do lado errado da geometria. Há outra coisa que aumenta em vez de diminuir, e é uma espécie de ganido. As mulheres emitem ganidos cada vez mais altos à medida que se aproximam de Bibu e dos outros dois" (VIGNA, 2006, p. 28). Um pouco depois, ao mencionar uma discussão acalorada entre um casal de meia-idade na mesa ao lado, Shirlei afirma que

$\mathrm{Na}$ mesa grande não querem ouvir e não ouvem, continuando a cacarejar. Além de Biby, há agora outros nomes a meu dispor: Caíque e Tony. As mulheres se chamam Agri (Egrid, Agrid), Dô (Dorothy) e Quinque ou Quilde, que é a mais calada. Depois de um "muito prazer" inicial, Quinde só sorri para todos. Ela é quem 
provavelmente ficou com minha vaga, porque é isso que eu faria caso estivesse naquela mesa e tivesse samba no pé: sorriria sem parar até meus dentes caírem de cansaço.

Há sempre um dramazinho babaca para qualquer lugar que se olhe. (VIGNA, 2006, p. 30)

Ao atribuir aos ruídos produzidos pelas mulheres o peso de sons - de conotações bem específicas, por sinal - emitidos por cães e galinhas, Shirley faz um claro juízo de valor sobre a condição feminina, de modo bastante desabonador. Também é interessante constatar que os homens referidos no trecho dado têm seus nomes lembrados enquanto os nomes femininos não merecem consideração de Shirley, como se não tivessem importância. É o mesmo juízo depreciativo exibido quando, após ficarem sozinhas à mesa, as mulheres "estão ocupadas cochichando entre si, debruçadas na mesa para ficarem mais próximas umas das outras. Com mãos de rapina pegam, de minuto a minuto os copos e enchem a cara de uísque, rápidas, aproveitando que os homens estão ausentes" (VIGNA, 2006, p. 32). O juízo de valor que Shirley expressa pouco depois reforça a ideia de que as moças em volta da mesa grande são fúteis, alienadas que têm apenas preocupações com bobagens que são desprezíveis aos olhos irônicos da protagonista do romance: "No restaurante, mais palavras sem sentido vinham das mulheres tingidas de louro. Top (um tipo de blusa). Baggy (um tipo de calça), spencer (não sei o que é mas já soube), escarpin (que sempre achei que tinha a ver com os três mosqueteiros)" (VIGNA, 2006, p. 33). Mais adiante, quando os homens voltam à mesa com presentes de conotação íntima e os entregam às moças, a cena é descrita como uma celebração da tolice feminina: "As outras mulheres põem seus novos sutiãs por cima da roupa, as calcinhas estão, à guisa de lenço, enroladas na cabeça. [...] Dô ganhou de Buby uma enorme calça elástica. Quando ela exibe a calça, as risadas ficam mais falsas do que já são” (VIGNA, 2006, p. 35).

Pode-se notar que ao mesmo tempo em que os homens só falam em “assuntos sérios” que Shirley se esforça para entender, as mulheres são consideradas frívolas, quando não desonestas exploradoras de seus predicativos físicos. As moças a que Shirley se refere são um modelo de comportamento feminino bastante depreciativo: são vistas como dis- 
simuladas, vulgares, escandalosas e não confiáveis, fazem um papel ridículo em público e não se incomodam com o decoro que certas situações sociais exigem, fazendo, assim, questão de exibir uma conduta não recomendada pelos padrões de recato ditados pela dominação masculina. E assimilados por Shirley, que replica um discurso antigo e preconceituoso que desvaloriza a figura feminina e, de acordo com Bourdieu (2014, p. 99) "não se trata mais que de um reforço do efeito da relação fundamental que institui a mulher na posição de ser-percebido condenado a se ver através das categorias dominantes, isto é, masculinas".

A ideia mais preconceituosa que a narrativa traz está nas possibilidades de mudança profissional que se oferecem a Shirley. É fato que “o equipamento sexual de seu corpo é exatamente um desses recursos à disposição que, como todos os outros, pode ser usado para todo o tipo de propósito e colocado a serviço de uma ampla gama de objetivos (BAUMAN, 2005, p. 93), mas direcionar as perspectivas profissionais tão somente para a área do comércio sexual é o único caminho indicado a Shirley Marlone. Embora tenha qualificação profissional, já que ela afirma que "fazia sites para clientes (inexistentes) do cara. Cursei dois anos de computação. Minha família já foi de classe média, ainda acha que é" (p. 15) e, mais além, que "era sede de uma ONG. Era para eu dar umas aulas de web design para jovens do Borel, mas não havia verba no momento. Dei mesmo assim" (p. 141), fazer programas sexuais é a única possibilidade de sobrevivência que lhe é sugerida. É interessante notar que, mesmo dentro de uma sociedade calcada nos padrões de dominação masculina, outros caminhos poderiam ser sugeridos para um travesti, tais como salões de beleza, espetáculos teatrais, o mundo da moda ou até mesmo o trabalho no hotel cinco estrelas que Shirley tanto frequenta. Mas fazer programas é a única alternativa que se põe a seu alcance e tal força há no delineamento da hipótese da prostituição como o único ofício para Shirley que até mesmo sua amiga Meire o propõe como o meio de vida para uma pessoa com certas questões de gênero a resolver, como se vê em:

Há adendos possíveis de serem feitos. A própria Meire, por exemplo. Ela me fez uma proposta, nas suas palavras, "proposta comer- 
cial". [...] A proposta de Meire é eu ir, todo dia, no finzinho da tarde, para o bar do hotel, onde conhecerei pessoas interessantes, já que tenho, diz ela, cultura e papo, mais cultura do que papo, acrescenta, porque não ia ser trancada no quarto e sem falar com ninguém que eu ia arranjar trabalho. [...]

$\mathrm{Na}$ hora ela não chega a detalhar que tipo de trabalho haveria para mim no bar do hotel. (VIGNA, 2006, p. 43-44)

Por mais que Shirlei-personagem tente se desligar de sua persona masculina, não o consegue totalmente, deixando à parte sua cautela em dissimular sua identidade. Isso ocorre em marcantes ocasiões, como quando resolve, dez anos depois do desaparecimento de Dô, visitar Meire, a quem observa, pensando "Vou voltar. Está tudo arrumado. Fico pensando como será esta trepada. Acho que vai pintar. Será engraçado. Afinal, um homem e uma mulher, só que ao contrário" (p.148). As falas de Shirley denotam que "a presença constante da fraude no enredo composto de mentiras confessas também desmascara a falsidade do ideal de mulher. Ele é negado, criticado, desconstruído e até assassinado, mas continua a perseguir a protagonista” (MIRANDA, 2008, p. 54). Por mais que tente "deixar ele lá e vir", Shirley acaba se traindo em gestos, em pensamentos, em palavras, revelando seu interior forjado nos moldes da dominação masculina que demonstra que

Homossexuais, tendo necessariamente sido educados como heterossexuais, interiorizaram o ponto de vista dominante e podem assumir este ponto de vista a respeito de si mesmos (o que os inclina a uma espécie de discordância cognitiva e avaliativa capaz de contribuir para sua especial clarividência), bem como compreender o ponto de vista dos dominantes melhor do que eles podem compreender o seu. (BOURDIEU, 2014, p. 51)

Shirley-autora, ao sentar-se diante da tela do computador, inventou uma trama policial cheia de aventuras mirabolantes e falas enigmáticas, arquitetou possibilidades e plantou detalhes interessantes, enredou o leitor em muitas reviravoltas e nada esclareceu sobre o mistério que envolve uma Shirley-personagem incomum, que viveu uma aventura única, 
vertiginosa. Shirley-autora, que vive uma acomodada e estável relação afetiva com Bubi, a quem passou "a chamar, obediente (me pediu) de Tião", que mora em um "prédio velho sem elevador embora muito simpático", sentando-se diante da tela do computador, deixou entrever sua mentalidade dominantemente masculina ao construir a protagonista $\mathrm{da}$ narrativa.

\section{Considerações Finais}

Elvira Vigna costuma prestigiar personagens "em constantes movimentos entre máscaras, identidades e corpos. Ela está concatenada com paradigmas contemporâneos como a da diferença sexual, além dos papéis dos gênero, mostrando o lado arbitrário das normas" (LEAL, 2012, p. 44) e no romance Deixei ele lá e vim tem-se essa marca bastante evidenciada. Trata-se de uma história em que nada é o que parece ser. Em suas idas e vindas temporais, o enredo toma vulto ao passo que o leitor conecta as pistas e elabora sentidos que podem ser construídos e reconstruídos, devido à engenhosidade da estrutura narrativa concebida por Vigna. Utilizando o recurso da falsa autoria, a romancista diferencia sutilmente Shirley-personagem de Shirley-autora.

Narradora não confiável e empenhada, de acordo com Góis (2013) e com Amorim e Zolin (2014), em não esclarecer os eventos de sua narrativa, Shirley-autora acaba por revelar sua adesão às estruturas de dominação masculina, nos moldes de Bourdieu (2014), assimiladas e reproduzidas na criação de Shirley-personagem e nas relações que esta mantém com outras personagens do enredo e ainda em relação à imagem que esta faz de si mesma. Por mais que Shirley-personagem insista em abandonar de vez sua identidade masculina, ela vive sempre assombrada por padrões (de estética, de comportamento, de pensamento, de vida) absorvidos a partir do pensamento androcêntrico que a faz sentir-se inadequada, feia, humilhada, infeliz e eternamente insatisfeita em sua procura por uma identidade, conforme Bauman (2005), que a ajuste ao mundo - um ajuste que ela tenta obter inventando verdades ou contando mentiras sobre sua trajetória numa sociedade machista à qual Shirley luta para se adequar. Em seu esforço para se adaptar ao 
mundo dominado pela mentalidade masculina, a Shirley Marlone que declara abertamente "minto desde menina, sou profissional em mentiras" (p. 138) pode estar fazendo a única declaração confiável de todo o romance Deixei ele lá e vim.

\title{
HE CAME WITH ME: \\ AUTHOR, NARRATOR, GENDER AND MALE DOMINATION IN A NOVEL BY ELVIRA VIGNA
}

\begin{abstract}
This article aims to analyze the figure of the author and the figure of the narrator in the detective novel Deixei ele lá e vim, by Elvira Vigna and discuss the dimension of androcentric thinking on wich certain social structures are based. Thus, definition of author and narrator as well as issues in relation to gender and male domination are fundamental to the elaboration of this study. Our purposse is to show that the protagonist of the examinated novel is constructed in such a way that reveals the support to the structures of male domination that guide their relationship in a narrative full of ambiguities.
\end{abstract}

KEYWORDS: Author; Male Domination; Gender; Narrator

\section{REFERÊNCIAS}

BAUMAN, Zygmunt. Identidade: entrevista a Benedetto Veccbi/Zygmunt Bauman; tradução, Carlos Alberto Medeiros. Rio de Janeiro: Jorge Zahar Editor, 2005.

BOURDIEU, Pierre. A dominação masculina. Rio de Janeiro: BestBolso, 2014.

BUTLER, Judith. Problemas de gênero: feminismo e subversão da identidade. Tradução Renato Aguiar. Rio de Janeiro: Civilização Brasileira, 2003.

GÓIS. Edma Cristina Alencar de. Cartografias dissonantes: corporalidades femininas em narrativas brasileiras contemporâneas.2013. 196 f. Tese (Doutorado em Literatura) - Instituto de Letras, Departamento de Teoria Literária e Literaturas, Universidade de Brasília, Brasília, 2013.

LEAL, Virgínia Maria Vasconcelos.O gênero como construção nos romances de cinco escritoras brasileiras contemporâneas. In: DALCASTAGNE, Regina; LEAL, Virgínia Maria Vasconcelos (orgs.). Deslocamento de Gênero na narrativa brasileira contemporânea. Vinhedo: Editora Horizonte, 2010. P. 65-96.

. Campo Literário e Identidade de Gênero: diálogos (im)possíveis entre Editora Malagueta e Elvira Vigna. Revista Iberi@@L - Revue d'etudes ibériques et ibéro-americaines, Paris, 
número 2, pp. 37-50, Automne 2012. Disponível em http://iberical.parissorbonne.fr/numeros/numero-2-automne-2012/. Acesso em 20/09/2017.

MIRANDA, Adelaide Calhman de. Gêneros indefinidos e corpos inadequados revelam o ideal feminino inatingível, em Deixei ele lá e vim, de Elvira Vigna. Revista Estudos de Literatura Brasileira Contemporânea, Brasília, n. 32, p. 47-56,julho-dezembro de 2008.

MOISÉS, Massaud. Dicionário de termos literários. 12a . ed. São Paulo: Cultrix, 2004.

NEVES, Lígia Amorim. ZOLIN, Lúcia Osana.O narrador não confiável como estratégia para a desconstrução de gênero em Deixei ele lá e vim, de Elvira Vigna. Revista Fórum Identidade, Itabaiana, v. 15, p. 119-136, jan./jun. 2014. Disponível em www.seer.ufs.br/index.php/forumidentidades/article/download /.../2664 Acesso em: 10 jul. 2015.

SANTOS, Luiz Alberto Brandão; OLIVEIRA, Silvana Pessôa de. Sujeito, Tempo e Espaço Ficcionais. São Paulo: Martins Fontes, 2001.

TODOROV, Tzvetan. As estruturas narrativas. Tradução Leyla Perrone-Moisés São Paulo: Perspectiva, 2013.

VIGNA, Elvira. Deixei ele lá e vim. São Paulo: Companhia das Letras, 2006.

Recebido em: 30/09/2017.

Aprovado em: 08/12/2017. 